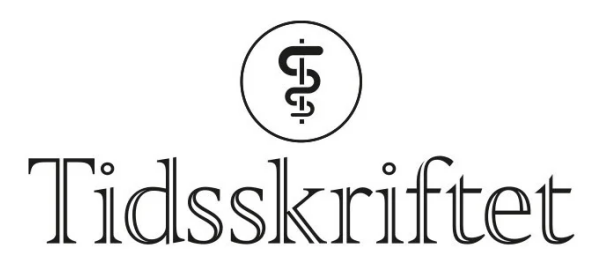

DEN NORSKE LEGEFORENING

\title{
Reseptlegemidler som ikke hentes
}

\author{
KORT RAPPORT
}

BENT ASGEIR LARSEN

bent@karrestad.no

Karrestad Legekontor

Halden

og

Norsk Helsenett

Bent Asgeir Larsen er spesialist i allmennmedisin og fastlege. Han er medisinskfaglig rådgiver og klinisk forvalter for kjernejournal i Norsk Helsenett.

Forfatteren har fylt ut ICMJE-skjemaet og oppgir ingen interessekonflikter.

\section{BAKGRUNN}

Kjernejournal mottar kopi av alle e-resepter og utleveringer fra norske apotek. Noen eresepter utløper uten at det blir utlevert noe på dem. Målet med studien var å se hvor mange e-resepter som passerte utløpsdato uten at det ble foretatt noen utlevering, og hva slags resepter dette var.

\section{MATERIALE OG METODE}

Det ble gjort et anonymisert uttrekk fra kjernejournal av alle e-resepter og utleveringer for perioden 1.3.2016-1.3.2018. Antall e-resepter som utløp uten at noe ble hentet ut på dem, ble summert og sortert etter hvilket preparat resepten gjaldt. Det ble beregnet prosentandel uavhentede resepter for hvert preparat.

\section{RESULTATER}

Av 47771233 registrerte e-resepter i perioden utløp 5934589 (12\%) uten at det ble foretatt noen utlevering. Innenfor de enkelte preparatgruppene varierte andelen ikke-utleverte eresepter fra $4 \%$ for z-hypnotika til $49 \%$ for glukagon.

\section{FORTOLKNING}

Undersøkelsen antyder at det er flere årsaker til at reseptene ikke ekspederes.

\section{HOVEDFUNN}

$12 \%$ av alle e-reseptene som ble skrevet ut i perioden 1.3.2016-1.3.2018 ble aldri hentet ut på apotek.

Andelen ikke avhentende resepter varierte fra $4 \%$ (z-hypnotika) til $49 \%$ (glukagon). 
I den elektroniske tjenesten kjernejournal lagres en komplett legemiddelhistorikk for alle pasienter. Denne historikken består dels av kopi av alle e-resepter og dels av utleveringsmeldinger fra apotek. Utleveringsmeldinger mottas både på papirresepter (inkludert telefon- og telefaksresepter) og på e-resepter. Når kjernejournal mottar en utleveringsmelding på en e-resept, kobles utleveringen mot resepten og eventuell gjenværende mengde blir beregnet.

Etter dagens regelverk utløper - med noen unntak - de fleste resepter etter ett år. De fleste e-resepter i kjernejournal eldre enn ett år er således utløpt og kan ikke lenger utleveres på apotek. Kjernejournal er en reservasjonsløsning, det vil si at alle som ikke aktivt har reservert seg, vil ha en kjernejournal. Per mars 2019 var det i underkant av 0,1\% av befolkningen som hadde reservert seg. Kjernejournal lagrer reseptdata i tre år, men startdato settes til den dagen pasienten fikk opprettet kjernejournal. Kjernejournal startet opp i 2013, men var ikke fullt utrullet til hele befolkningen før våren 2017.

I forbindelse med kvalitetskontroll i kjernejournal ble det lagt merke til at det var et forholdsvis stort antall e-resepter hvor gyldighetstiden hadde utløpt uten at det var foretatt noen utlevering. Man ønsket derfor å se nærmere på hva slags resepter dette var for å prøve å forstå hvorfor pasientene ikke hentet ut legemidlene på disse reseptene.

\section{Materiale og metode}

I mars 2019 ble det tatt ut et anonymisert uttrekk av e-resepter som var over ett år gamle. Ekstraksjonen tok for seg resepter fra toårsperioden 1.3.2016-1.3.2018. Uttrekket var godkjent av forvaltningen av kjernejournal i Direktoratet for e-helse og vurdert og godkjent av personvernansvarlig i Direktoratet for e-helse. Vi talte opp totalt antall resepter innen hver preparatgruppe og antallet resepter det ikke var noen utleveringer på.

Resepter fordelt på de enkelte preparater ble nærmere gjennomgått. Alle preparater hvor det var gjort minst én forskrivning i toårsperioden, ble registrert, men man valgte å sette en grense på 1o ooo resepter innen én preparatgruppe for inklusjon i analysen. Denne grensen ble skjønnsmessig valgt for å unngå tilfeldige variasjoner i grupper med få resepter.

Resultater presenteres deskriptivt med antall, andel, gjennomsnitt og standardavvik.

\section{Resultater}

I perioden 1.3.2016-1.3.2018 mottok kjernejournal 47771233 e-resepter. Av disse var 5934589 $(12 \%)$ resepter uten utlevering.

Preparatet som hadde relativt høyest andel av ikke-avhentede resepter var glukagon, hvor 10621 av 21699 (49\%) ikke ble hentet. Tabell 1 viser de ti preparatene med høyest andel ikkeutleverte resepter, og tabell 2 viser de ti preparatene med flest resepter uten utlevering sortert etter absolutte tall.

\section{Tabell 1}

De ti hyppigste ikke-utleverte e-reseptene registrert i kjernejournal i tidsrommet 1.3.20161.3.2018, sortert etter relativ hyppighet.

\begin{tabular}{|lrrr|}
\hline Preparat & $\begin{array}{l}\text { Totalt } \\
\text { antall e- } \\
\text { resepter }\end{array}$ & $\begin{array}{l}\text { Resepter uten } \\
\text { utleveringer }\end{array}$ & \% uavhentet \\
\hline Glukagon & 21699 & 10621 & 49 \\
\hline Laktulose & 52222 & 21339 & 41 \\
\hline
\end{tabular}




\begin{tabular}{|lccr|}
\hline Preparat & $\begin{array}{l}\text { Totalt } \\
\text { antall e- } \\
\text { resepter }\end{array}$ & $\begin{array}{l}\text { Resepter uten } \\
\text { utleveringer }\end{array}$ & \%avhentet \\
\hline Vareniklin & 60585 & 22208 & 37 \\
\hline Lokalanestetika, kombinasjoner (krem/salver) & 11077 & 4039 & 36 \\
\hline Ferroglysinsulfat & 27412 & 9986 & 36 \\
\hline Alginsyre & 12182 & 4356 & 35 \\
\hline Ekspektorantia, kombinasjoner & 13706 & 4851 & 34 \\
\hline Natriumpikosulfat & 31469 & 10817 & 34 \\
\hline Ispaghula & 13191 & 4456 & 32 \\
\hline Ferrosulfat & 18341 & 56447 & 37 \\
\hline
\end{tabular}

\section{Tabell 2}

De ti hyppigste ikke-utleverte e-reseptene registrert i kjernejournal i tidsrommet 1.3.20161.3.2018, sortert etter absolutte tall.

\begin{tabular}{|lccr|}
\hline Preparat & $\begin{array}{l}\text { Totalt } \\
\text { antall e- } \\
\text { resepter }\end{array}$ & $\begin{array}{l}\text { Resepter uten } \\
\text { utleveringer }\end{array}$ & \% uavhentet \\
\hline Paracetamol & 1498104 & 211662 & 14 \\
\hline Salbutamol & 812079 & 129049 & 16 \\
\hline Diklofenak & 816181 & 121660 & 15 \\
\hline Cetirizin & 719413 & 102548 & 14 \\
\hline Kolekalsiferol (vitamin $\left.\mathrm{D}_{3}\right)$ & 372579 & 91387 & 13 \\
\hline Pantoprazol & 697468 & 89849 & 10 \\
\hline Metoprolol & 837688 & 86078 & 14 \\
\hline Desloratadin & 607788 & 85036 & 9 \\
\hline Tramadol & 959584 & 82408 & 11 \\
\hline Levotyroksinnatrium & 722340 & 80953 & \\
\hline
\end{tabular}

Gruppene med lavest andel ikke-utleverte resepter tilhørte z-hypnotika, zopiklon og zolpidem, begge med $4 \%$ ikke-utleverte resepter.

Blant alle typer antibiotika ble gjennomsnittlig 9,6\% (standardavvik 1,6\%) av reseptene ikke hentet. Metenamin var det antibiotiske preparatet som hadde høyest andel ikkeavhentede resepter, $13 \%$.

\section{Diskusjon}


I perioden 1.3.2016-1.3.2018 ble $12 \%$ av alle e-resepter registrert i kjernejournal ikke hentet ut på apotekene. Hvorfor blir ikke resepter hentet ut? Denne studien gir ingen sikre svar på dette spørsmålet, men tallene antyder noen faktorer som kan være årsaken.

Mange av legemidlene på reseptene som ikke hentes ut, kan kjøpes uten resept. Det er sannsynlig at pasientene - til tross for høyere pris i en del tilfeller - velger reseptfritt alternativ i stedet for å løse inn resepten.

Den andre gruppen som peker seg ut, er anfalls- og behovsmedikamenter. Her er det nok en del som ønsker å ha en resept «i beredskap», men som likevel ikke løser inn resepten før den utløper.

Noen pasienter autoseponerer legemidler og henter dermed ikke ut på resepten, og noen ganger får pasienten beskjed av lege om å slutte med et legemiddel uten at e-resepten tilbakekalles.

Mangelfull medikamentetterlevelse er en annen mulig årsak.Det er en kjent sak at noen pasienter ikke følger opp legens anbefalinger om bruk av legemidler. I en dansk studie fra 2014 fant man at 9,3\% av pasientene som startet opp med en ny medikamentell behandling i allmennpraksis, ikke hentet ut legemidlene (1). I en lignende studie fra Island, der man sammenlignet antallet utskrevne e-resepter fra allmennleger med utleveringer, fant man at $6,2 \%$ av reseptene ikke ble hentet ut (2).

Men det er også noen mulige forklaringer som ligger hos forskriver.

Forvaltningsavdelingen for e-resept har studert kvaliteten i den nasjonale databasen Reseptformidleren og funnet at ca. $15 \%$ av pasientene har doble resepter her (3). I en del tilfeller er dette selvsagt korrekt, men dette kan også forekomme ved at behandler endrer en legemiddelbehandling og sender ny e-resept til databasen uten å tilbakekalle den gamle. Dermed blir det liggende en fortsatt gyldig e-resept med gammel dosering som pasienten ikke skal bruke. Det kan ikke utelukkes at en del av de reseptene som i denne undersøkelsen fremkommer som ikke utleverte, er slike doble resepter.

En annen mulig årsak til ikke-utleverte e-resepter er bruk av papirmultidose. Når pasienter går over til multidose, sendes et ordinasjonsark til apoteket. Dette ordinasjonsarket fungerer som en papirresept i inntil ett år. Man har i kjernejournal sett at mange leger likevel lager e-resepter på de legemidlene som pakkes i multidose. Siden apoteket utleverer på bakgrunn av papirrekvisisjonen, blir e-reseptene stående som ikke-utlevert. Det er sannsynlig at en del av de e-reseptene som fremkommer i denne studien, er slike multidoselegemidler.

\section{BEGRENSNINGER}

Siden kjernejournal ikke var fullt utbredt før våren 2017, utgjør utvalget ikke $100 \%$ av de ereseptene som ble skrevet ut i denne perioden. Det er likevel ikke grunn til å tro at det relative forholdet mellom utskrevne og ikke-utleverte resepter påvirkes i vesentlig grad av dette. Kjernejournal var tatt i bruk i alle helseregioner på dette tidspunktet, men det var spredte områder både nord, sør og øst som fortsatt ikke hadde startet opp. Andelen papirresepter i samme periode utgjør i overkant av $10 \%$ av det totale antallet resepter. Denne vurderingen gjelder kun e-resepter, men det er vanskelig å tro at forholdet er vesentlig annerledes for papirresepter.

Artikkelen er fagfellevurdert.

\section{LITTERATUR}

1. Pottegård A, Christensen R, Houji A et al. Primary non-adherence in general practice: a Danish register study. Eur J Clin Pharmacol 2014; 70: 757-63. [PubMed][CrossRef]

2. Linnet K, Halldórsson M, Thengilsdóttir G et al. Primary non-adherence to prescribed medication in general practice: lack of influence of moderate increases in patient copayment. Fam Pract 2013; 30: 
69-75. [PubMed][CrossRef]

3. Kvalitet i e-resept. Forprosjektrapport IE-1004. Oslo: Direktoratet for e-helse, 2017. https://nhn.no/media/2623/kvalitet-i-e-resept-2017.pdf Lest 9.7.2020.

Publisert: 28. september 2020. Tidsskr Nor Legeforen. DOI:10.4045/tidsskr.19.0577

Mottatt 10.9.2019, første revisjon innsendt 26.11.2019, godkjent 9.7.2020.

(C) Tidsskrift for Den norske legeforening 2023. Lastet ned fra tidsskriftet.no 26. april 2023. 